\title{
Radical change of Zn speciation in pig slurry amended soil: key role of nano-sized sulfide particles
}

\author{
Thiago Augusto Formentini ${ }^{\mathrm{a}, \mathrm{c}}$, Samuel Legros ${ }^{\mathrm{b}, \mathrm{h}}$, Cristovão Vicente Scapulatempo Fernandes ${ }^{c}$, \\ Adilson Pinheiro ${ }^{d}$, Maureen Le Bars ${ }^{e}$, Clément Levard ${ }^{e}$, Fábio Joel Kochem Mallmann ${ }^{f}$, \\ Milton da Veiga ${ }^{\mathrm{g}}$, Emmanuel Doelsch ${ }^{\mathrm{h}}$.

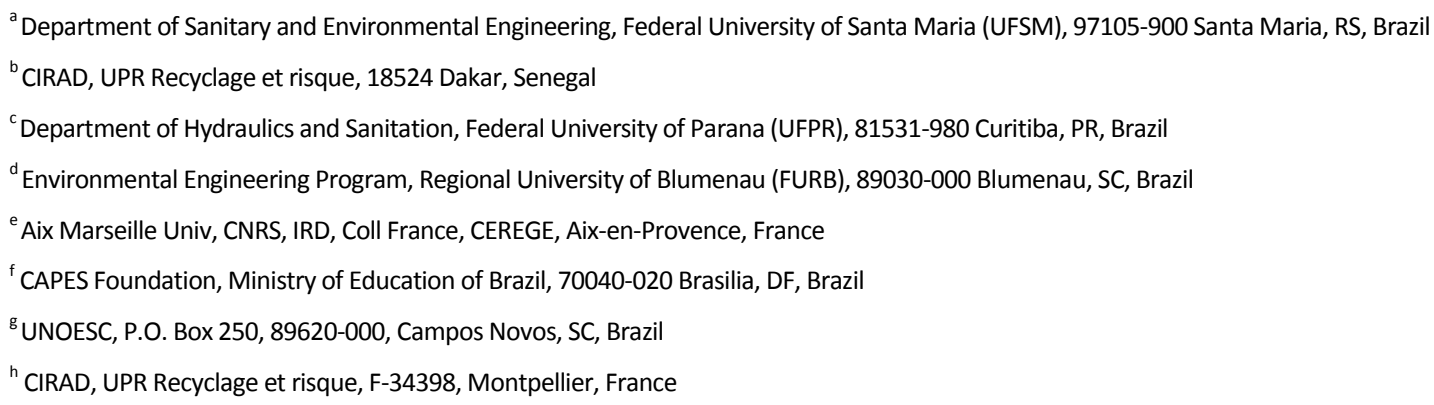

\begin{abstract}
Spreading livestock manure as fertilizer on farmlands is a widespread practice. It represents the major source of heavy metal(loid)s (HM) input in agricultural soils. Since zinc ( $\mathrm{Zn})$ is present at high concentrations in manure, it poses special environmental concerns related to phytotoxicity, groundwater contamination, and introduction in the food chain. Therefore, investigations on the fate and behavior of manure-borne $\mathrm{Zn}$, when it enters the soil environment, are necessary to predict the environmental effects. Nevertheless, long-term field studies assessing Zn speciation in the organic waste matrix, as well as within the soil after manure application, are lacking. This study was designed to fill this gap. Using SEM-EDS and XAS analysis, we reported the following new results: (i) ZnS made up $100 \%$ of the $\mathrm{Zn}$ speciation in the pig slurry (the highest proportion of ZnS ever observed in organic waste); and (ii) ZnS aggregates were about 1- $\mu \mathrm{m}$ diameter (the smallest particle size ever reported in pig slurry). Moreover, the pig slurry containing ZnS was spread on the soil over an 11-year period, totaling 22 applications, and the resulting $\mathrm{Zn}$ speciation within the amended soil was analyzed. Surprisingly, ZnS, i.e. the only species responsible for a nearly 2 -fold increase in the $\mathrm{Zn}$ concentration within the amended soil, was not detected in this soil. Based on SEM-EDS and XAS observations, we put forward the hypothesis that $\mathrm{Zn}$ in the pig slurry consisted of nanosized ZnS crystallites that further aggregated. The low stability of ZnS nanoparticles within oxic and complex environments such as the studied soil was the key explanation for the radical change in pig slurry-borne $\mathrm{Zn}$ speciation after long-term amendments.
\end{abstract}




\section{2-LINE SUMMARY}

Nano-sized ZnS particles accounted for $100 \%$ of the $\mathrm{Zn}$ speciation in the pig slurry (PS). PS-borne $\mathrm{Zn}$ underwent rapid conversion after spreading on the soil and was subsequently bound to soil minerals and OM.

Keywords: Trace elements; agricultural recycling; environmental impact; spectroscopy; microscopy.

\section{INTRODUCTION}

There were nearly 1 billion pigs in the world in 2013. In the same year, China was the largest producer, with 475.9 million pigs, followed by the United States (64.8 million) and Brazil (36.7 million) (FAO, 2013). Pig manure is thus produced in massive quantities. In 2008, swine activity generated more than 900 million $\mathrm{m}^{3}$ of pig slurry (PS) in the European Union alone (EC, 2014). Spreading manure as fertilizer on agricultural lands is the most common destination. Nevertheless, soil pollution by nitrate, phosphorus and heavy metal(loid)s (HM) has raised concern (Legros et al., 2013; Mallmann et al., 2012; Hernández et al., 2006). Whereas mobility and transfer mechanisms of the former have been substantially studied and are fairly well understood, the fate of exogenous HM in soils is still under ongoing investigation.

Zinc $(\mathrm{Zn})$ is added to livestock feed owing to its growth and antibiotic attributes (Jondreville et al., 2003). However, most of this $\mathrm{Zn}$ is excreted in the manure and subsequently spread on the soil (Revy et al., 2003). Livestock manure currently represent $78 \%$ and $51 \%$ of total $\mathrm{Zn}$ inputs in agricultural soils in France and China, respectively. In China, Zn concentrations in pig manure have nevertheless increased about sixfold from the early 1990s to 2003 (Romeo et al., 2014 and references therein). Increased Zn concentrations may lead to phytotoxicity, introduction in the food chain via accumulation in plant tissues and grains, or groundwater contamination through leaching (Lipoth and Schoenau, 2007: Gräber el al., 2005; L’Herroux et al., 1997).

HM speciation in wastes and waste-amended soils is a key factor in determining their mobility, bioavailability, and potential toxicity in the soil-water-plant system. Speciation takes into account chemical and physical properties such as the element isotopic composition, oxidation state, coordination and molecular structure (Reeder et al., 2006). Therefore, 
speciation-based investigations of the fate of organic waste-borne $\mathrm{Zn}$ is necessary to better predict the environmental effects of this widespread recycling practice (Tella et al., 2016).

Sequential extraction methods are most used to assess $\mathrm{Zn}$ speciation. This approach has been applied to examine organic waste (L'herroux et al., 1997) and organically-amended soils, mostly using controlled bench scale and short-term conditions (Guan et al., 2011; Plekhanova, 2012; Qiao et al., 2003; Hseu, 2006). Only a few studies have involved long-term field experiments (L'Herroux et al., 1997; Asada et al., 2012; Girotto et al., 2010). Although sequential extractions are straightforward and easy-to-use, they have major shortcomings, such as incomplete dissolution of target phases and/or dissolution of non-target species (Doelsch et al., 2008). Therefore, the obtained fractions, and consequently the research findings and interpretation, depend on the chosen extraction procedure.

On the contrary, XAS is a powerful structural technique for direct determination of trace element speciation in complex samples. XAS has been used in a few studies to assess HM speciation within PS (Legros et al., 2010a; Legros et al., 2010b; Lin et al., 2013) and soils amended with both sewage (Kirpichtchikova et al., 2006) and biosolids (Mamindy-Pajany et al., 2014). Nevertheless, XAS studies to assess Zn speciation within soils after PS amendment via long-term field experiments are lacking.

The present study takes into account a unique combination of three approaches. We assessed $\mathrm{Zn}$ speciation: (i) in the PS matrix and within the soil that had received PS amendments; (ii) by using a combination of state-of-the-art physical techniques: X-ray powder diffraction (XRD), scanning electron microscopy with X-ray microanalysis (SEM-EDS), and XAS; (iii) in a long-term field experiment (11 years). We considered qualitative and quantitative characterization of each $\mathrm{Zn}$ species detected in the PS and within the soil to obtain a comprehensive description on $\mathrm{Zn}$ behavior throughout the waste recycling process, from slurry storage until its fate within the soil after 11 years of land application.

\section{MATERIALS AND METHODS}

2.1 Field experiment and soil characterization

The experiment was conducted in the demonstration field of the Cooperativa Regional Agropecuária de Campos Novos (Copercampos), in Campos Novos, Santa Catarina State, 
southern Brazil. The basaltic soil is classified as Rhodic Hapludox (USDA, 2003), composed of $67.8 \%$ clay, $30.8 \%$ silt and $1.4 \%$ sand (Mallmann, 2013).

Pig slurry had been spread in field plots at different application rates since the year 2000. A control soil was also monitored, with soil characteristics and crop management identical to those of the PS-amended soil, except for the absence of PS application. For the present study, the control soil and the soil that had received the highest PS application rate $200 \mathrm{~m}^{3}$ ha $^{-1}$ year $^{-1}$ - were selected for analysis, in order to provide the most marked contrast in $\mathrm{Zn}$ concentration between treatments. Moreover, we recently demonstrated that most of the $\mathrm{Zn}$ added to the soil via PS amendment had accumulated in the soil surface horizon (Formentini et al., 2015). Samples from the $0-5 \mathrm{~cm}$ soil layer were therefore used in the present study. Sampling was performed in June of 2011, after 11 years of soil amendment and 22 PS applications (two per year). Details on the soil characterization, crop rotation, seeding, sampling and $\mathrm{Zn}$ concentration through the soil profile may be found elsewhere (Formentini et al., 2015; Mallmann, 2013; Veiga et al., 2012).

\subsection{XRD analysis}

The mineral composition of the soil was identified with an X-ray diffractometer ( $X^{\prime}$ Pert Pro, Panalytical) running at $40 \mathrm{kV}$ and $40 \mathrm{~mA}$, using Co Ka radiation ( $\lambda=1.79 \AA$ ) with a linear detector ( $X^{\prime}$ Celerator) and a secondary flat monochromator. Samples were ground in an agate mortar and placed on zero background silicon sample holders with a few drops of ethanol. A counting time of $5.5 \mathrm{~s}$ per $0.033^{\circ}$ step was used for $2 \theta$ in the $4-80^{\circ}$ range. Phase identification was performed using XRD data analysis software (X'pert PRO Highscore plus) and its powder diffraction database (ICDD-PDF2).

\subsection{Pig slurry characterization}

Pig slurry was obtained from an anaerobic lagoon reservoir located on a pig finishing farm in Campos Novos, Brazil. The average physico-chemical characteristics of the PS added to the soil during the experiment were: $7.3 \mathrm{pH}, 2.25 \%$ dry mass content, and $43.0 \mathrm{~g} \mathrm{~m}^{-3}$ of $\mathrm{Zn}$ (Formentini et al., 2015). For the present study, a fresh PS sample was collected from the same anaerobic lagoon reservoir that had provided the samples used in the soil amendments. One 
portion of this sample was subjected to a size fractionation procedure, and fractions were dried to assess the dry matter content and Zn concentration in each fraction (Section 2.4). Another portion was subjected to the same particle size fractionation procedure, except that the obtained fractions were not dried and were used in liquid form for SEM-EDS analysis (Section 2.5). Finally, another portion of raw PS was freeze-dried $\left(-53^{\circ} \mathrm{C}\right)$, ground with a mortar and pestle, and pressed into pellets for powder EXAFS analysis, along with the soil samples (Section 2.6). The anaerobic conditions in the sample were preserved by collecting it near the bottom of the lagoon, with storage in a sealed plastic container without air bubbles, in the dark at $4^{\circ} \mathrm{C}$ prior to analysis.

2.4 Particle size fractionation of pig slurry

Filtration thresholds of $20 \mu \mathrm{m}, 0.2 \mu \mathrm{m}$ and $10 \mathrm{kDa}$ were used, leading to four particle size fractions: $>20 \mu \mathrm{m}, 20-0.2 \mu \mathrm{m}, 0.2 \mu \mathrm{m}-10 \mathrm{kDa}$, and $<10 \mathrm{kDa}$. Forty grams of liquid raw PS were passed through a $20 \mu \mathrm{m}$ nylon net filter (Whatman). The retained solid fraction was dried $\left(60^{\circ} \mathrm{C}, 48 \mathrm{~h}\right)$ and weighed, and it represented the $>20 \mu \mathrm{m}$ fraction. The filtrate was subjected to tangential flow filtration. The filtration system (KrosFlo, Spectrum Laboratories Inc.) was mounted with a $0.2-\mu \mathrm{m}$ pore size modified polyethersulfone (mPES) hollow filter and fed at 10 $\mathrm{ml} \mathrm{min}$. The system was adjusted for a filtration flow of $1 \mathrm{ml} \mathrm{min}^{-1}$ (10\% of the feeding flow) to allow sample recirculation. The permeate end was then closed and the system was fed with $10 \mathrm{ml}$ of demineralized water for recirculation in order to recover the retentate containing the 20-0.2 $\mu \mathrm{m}$-size fraction. This retentate was dried and weighed. The permeate was then passed through a 10-kDa pore size mPES hollow filter, which was mounted on the same filtration system, as a replacement for the previous filter. The same filtration procedure was conducted and the retentate containing particles in the $0.2 \mu \mathrm{m}-10 \mathrm{kDa}$ range was collected, dried and weighed. Lastly, the permeate containing the $<10 \mathrm{kDa}$ fraction (virtually lacking solid particles) was collected, acidified and stored prior to analysis.

The $>20 \mu \mathrm{m}$ fraction was not further analyzed due to its low (and insufficient) mass recovery, i.e. below $2 \%$ of the PS dry matter. Dried samples of the raw PS (10 g of liquid raw sample were dried at $60^{\circ} \mathrm{C}$ for $48 \mathrm{~h}$ ) and the $20-0.2 \mu \mathrm{m}$ and $0.2 \mu \mathrm{m}-10 \mathrm{kDa}$ fractions were subjected to acid digestion according to the EPA 3051A protocol (USEPA, 2007). The digested samples and the $<10 \mathrm{kDa}$ fraction were analyzed for their $\mathrm{Zn}$ concentrations using ICP-MS (NexION 300X, PerkinElmer). 
Liquid samples of the 20-0.2 $\mu \mathrm{m}$ particle-size fraction (filtered as described in Section 2.4) were analyzed using SEM-EDS. This fraction was selected because it contained most of the dry matter and $\mathrm{Zn}$ content (see Section 3.2). A small portion of sample was sonicated gently and a droplet was deposited onto a holey-carbon-coated 200 mesh CU-TEM grid. The sample was allowed to dry on the grid for a few hours prior to analysis. The scanning electron microscope (Philips XL30 SFEG, North Billerica, MA) was operated at $15 \mathrm{kV}$ accelerating voltage with a counting time of $60 \mathrm{~s}$ per point. Elemental analysis was performed with an energy dispersive spectrometer (Oxford Instruments, Oxfordshire, UK).

\subsection{EXAFS}

Zinc K-edge X-ray absorption spectra of the PS and soil samples were recorded on the FAME beamline at the ESRF, Grenoble, France. Finely ground samples were pressed into pellets and analyzed at liquid He temperature to prevent sample damage by photoreduction. The signal was acquired in fluorescence mode using a 30 element solid-state Ge detector (CANBERRA Industries Inc.). The spectra were the sum of 5 to 16 scans, depending on the $\mathrm{Zn}$ concentration and the noise level. $E_{0}$ was set at $9664.6 \mathrm{eV}$ for normalization and extraction of EXAFS spectra. Normalization and data reduction were performed according to standard methods (Doelsch et al., 2006) using Athena software (Ravel and Newville, 2005).

Previously background subtracted and normalized EXAFS spectra were subject to a least-square linear combination fitting (LCF) procedure over the $k$-range 2-9.9 $\AA^{-1}$. A library of $\mathrm{Zn}$ model compounds was used to identify and quantify the $\mathrm{Zn}$-bearing components in the samples. The residual parameter $\left[\operatorname{Res}=\Sigma\left(k^{2} \chi_{\text {exp }}-k^{2} \chi_{\text {model }}\right)^{2} / \Sigma\left(k^{2} \chi_{\text {exp }}\right)^{2}\right]$ and visual analysis of the fits were used as the fit criterion. LCF scenarios using only one and up to five fitting components were successively tested and evaluated based on the Res value and by visual observation of the quality and improvement of LCF when adding an extra component to previous best fits. LCFs with $n+1$ components were retained if the Res parameter was decreased by more than $20 \%$ as compared to the fit with $n$ components.

The sum of component weights in the best LCFs ranged from $90 \%$ to $112 \%$. Deviations from $100 \%$ may arise from variations in amplitudes due to overabsorption during spectra recording or from slight differences between the structure of $\mathrm{Zn}$ species existing in the samples 
and in the reference materials (Jacquat et al., 2009a; Manceau et al., 2002). Linear combination results were normalized to $100 \%$ for the comparison of the relative speciation between samples.

The library of $\mathrm{Zn}$ model compounds included: (i) primary and secondary $\mathrm{Zn}$ minerals and precipitates, i.e. synthetic ZnS nanoparticles (see Section 2.7), bulk ZnS (Aldrich), willemite $\left(\mathrm{Zn}_{2} \mathrm{SiO}_{4}\right)$, parahopeite $\left[\mathrm{Zn}_{3}\left(\mathrm{PO}_{4}\right)_{2} \bullet 4\left(\mathrm{H}_{2} \mathrm{O}\right)\right]$, zincite $(\mathrm{ZnO})$, franklinite $\left(\mathrm{ZnFe}_{2} \mathrm{O}_{4}\right)$, zinc hydroxide $\left[\mathrm{Zn}(\mathrm{OH})_{2}\right]$, smithsonite $\left(\mathrm{ZnCO}_{3}\right)$, zinc sulphate $\left(\mathrm{ZnSO}_{4}\right)$, zinc phosphate $\left[\mathrm{Zn}_{3}\left(\mathrm{PO}_{4}\right)_{2}\right]$, zinc nitrate $\left[\mathrm{Zn}\left(\mathrm{NO}_{3}\right)_{2}\right]$ and zinc aluminate $\left(\mathrm{ZnAl}_{2} \mathrm{O}_{4}\right)$; (ii) mineral surface sorption complexes at different loadings, i.e. Zn-HIM (hydroxy-interlayered mineral), Zn sorbed kaolinite, Zn sorbed ferrihydrite, Zn sorbed goethite, Zn sorbed birnessite, Zn sorbed kerolite, Zn-LDH (layered double hydroxide) and Zn sorbed hydrotalcite; and (iii) Zn-organic complexes: Zn-malate, Zncysteine, Zn-acetate, Zn-citrate, Zn-phytate, Zn-oxalate, Zn-malate, Zn-methionine, Znhistidine, Zn-phthalocyanine, Zn-glycine, Zn-galacturonic acid and Zn-pectin. For convenience, only the spectra of model compounds used in the best LCF scenarios to simulate the PS and soil sample spectra were presented and discussed (Sections 3.2.2 and 3.3.2).

\subsection{Synthesis and characterization of ZnS nanoparticles}

ZnS nanoparticles were synthesized by mixing high purity $\mathrm{ZnCl}_{2}$ and $\mathrm{Na}_{2} \mathrm{~S}$ in $\mathrm{N}_{2}$-purged deionized water. The $\mathrm{Zn}^{2+}$ concentration was set at $0.04 \mathrm{M}$, and different $\mathrm{S}^{2-}$ concentrations were used in order to obtain ZnS particles of different sizes. Three S/Zn molar ratios were used: 0.9, 1.1 and 3.0. After precipitation, the ZnS suspensions were aged for $48 \mathrm{~h}$ in the dark, at room temperature, with constant stirring. The final suspension pH levels were 3.6, 5.6 and 12.8, respectively. To remove excess salts, the suspensions were centrifuged at $3488 \mathrm{~g}$ for 30 min. The supernatant was then removed and the $\mathrm{ZnS}$ nanoparticles were dispersed in $20 \mathrm{~mL}$ of deionized water using an ultrasound bath and vortex. To exclude oxygen, the whole procedure was performed in a glovebox containing $100 \% \mathrm{~N}_{2}$.

One portion of each suspension was diluted and 7- $\mu \mathrm{L}$ drops were laid on a 400-mesh carbon film. Particle sizes were obtained after transmission electronic microscopy (TEM) characterization using a JEOL JEM-2010 microscope with a $200 \mathrm{keV}$ field emission source. The ZnS particle sizes were $2.49 \pm 0.29 \mathrm{~nm}, 4.73 \pm 1.11 \mathrm{~nm}$, and $5.92 \pm 0.64 \mathrm{~nm}$, respectively for the initial S/Zn molar ratios of 0.9, 1.1 and 3.0 (Supporting Information). Hence, the synthesized $\mathrm{ZnS}$ nanoparticles are hereafter denoted $\mathrm{ZnS}_{[2.5 \mathrm{~nm}]}, \mathrm{ZnS}_{[4.7 \mathrm{~nm}]}$, and $\mathrm{ZnS}_{[5.9 \mathrm{~nm}]}$. 
Another portion of each suspension was freeze-dried and the resulting powder was used for XRD analysis and to prepare thin PVP-diluted pellets for XAS analysis. XRD characterization was performed on the beamline 11-ID-B of the Advanced Photon Source (APS) at the Argonne National Laboratory (Lemont, USA). XAS spectra were recorded on the FAME beamline at ESRF, Grenoble, France. The spectra were obtained by merging two scans performed in transmission mode at liquid He temperature.

\section{RESULTS AND DISCUSSION}

3.1 Zn enrichment within the soil due to PS application

Figure 1 presents the $\mathrm{Zn}$ concentration within the $0-5 \mathrm{~cm}$ layer of the control and the amended soils, as well as the amounts of $\mathrm{Zn}$ added to the soil via PS application. The $\mathrm{Zn}$ concentration in the control soil was $100.4 \mathrm{mg} \mathrm{kg}^{-1}$, corresponding to $51.7 \mathrm{~kg} \mathrm{ha}^{-1}$ (soil bulk density $_{(0-5 \mathrm{~cm})}=1.03 \mathrm{~g} \mathrm{~cm}^{-3}$; Mallmann, 2013). The amount of $\mathrm{Zn}$ added to the soil over 11 years of PS application, at $200 \mathrm{~m}^{3} \mathrm{ha}^{-1} \mathrm{year}^{-1}$, was $94.6 \mathrm{~kg} \mathrm{ha}^{-1}$. If the whole amount of pedogenic and exogenous $\mathrm{Zn}$ were retained within the $0-5 \mathrm{~cm}$ layer of the amended soil, the expected $\mathrm{Zn}$ concentration would be $146.3 \mathrm{~kg} \mathrm{ha}^{-1}$. However, the observed concentration corresponded to $96.9 \mathrm{~kg} \mathrm{ha}^{-1}$. This means that the PS additions caused a nearly 2-fold increase in the $\mathrm{Zn}$ concentration within the $0-5 \mathrm{~cm}$ layer of the amended soil. Excess $\mathrm{Zn}$ accumulated in deeper layers, i.e. up to $30 \mathrm{~cm}$ (Mallmann, 2013; Formentini et al., 2015).

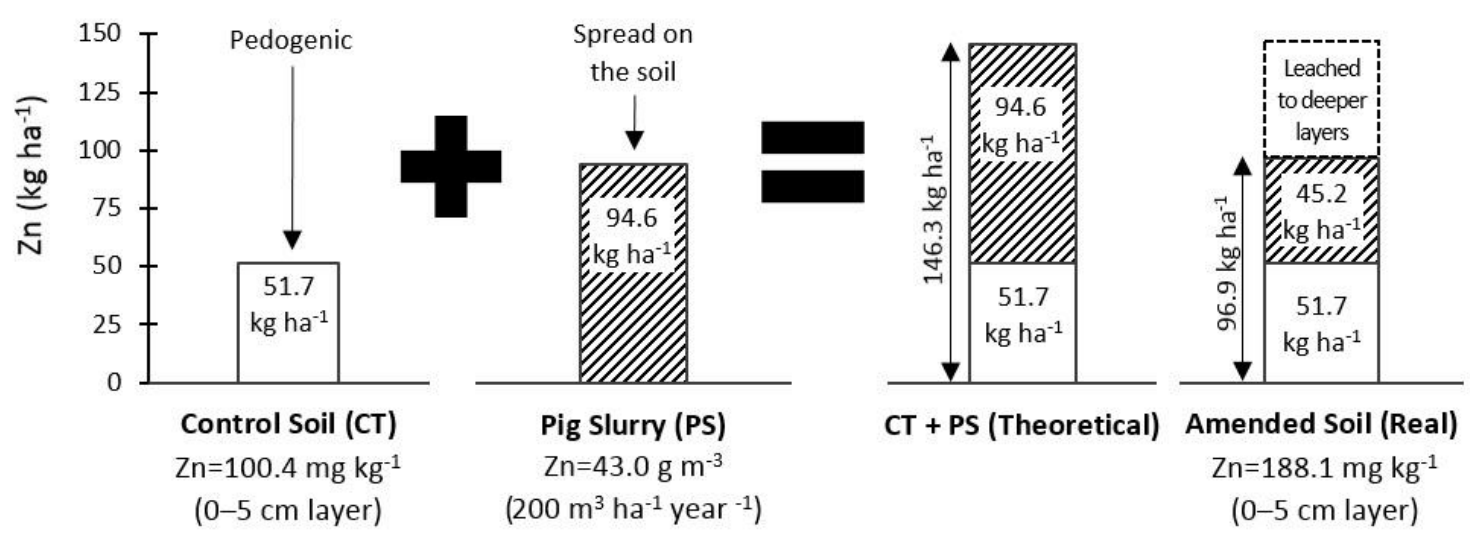

Figure $1-Z n$ concentration within the $0-5 \mathrm{~cm}$ layer of the control and amended soils, as influenced by the amount of $\mathrm{Zn}$ added to the soil via PS (adapted from Mallmann, 2013 and Formentini et al., 2015). 
3.2 Pig slurry

3.2.1 Co-location of $\mathrm{Zn}$ and $\mathrm{S}$ in sub-micron particle size

The PS dry matter was distributed as follows: $1.9 \%$ in the $>20 \mu \mathrm{m}$ fraction, $74.6 \%$ in the 20-0.2 $\mu \mathrm{m}$ fraction, and $17.9 \%$ in the $0.2 \mu \mathrm{m}-10 \mathrm{kDa}$ fraction. The dry matter content in the $<10 \mathrm{kDa}$ fraction was negligible. The mass recovery of the size fractionation procedure was $94.4 \%$. Assessment of the $\mathrm{Zn}$ concentration in the $>20 \mu \mathrm{m}$ fraction was not possible, due to its low dry matter content. In the $<10 \mathrm{kDa}$ fraction, only the dissolved $\mathrm{Zn}$ concentration was measured (9.6 $\mu \mathrm{g} \mathrm{L}^{-1}$ of the fraction). The $\mathrm{Zn}$ concentration in the $20-0.2 \mu \mathrm{m}$ fraction was 708.6 $\mathrm{mg} \mathrm{kg}^{-1}$ of dry matter, accounting for $91.8 \%$ of the $\mathrm{Zn}$ in the PS. The $\mathrm{Zn}$ concentration in the 0.2 $\mu \mathrm{m}-10 \mathrm{kDa}$ fraction was $1.7 \mathrm{mg} \mathrm{kg}^{-1}$ of dry matter, representing only $0.2 \%$ of the total $\mathrm{Zn}$.

The preponderance of $\mathrm{Zn}$ in the $20-0.2 \mu \mathrm{m}$ fraction was in line with previous results. Legros et al. (2010a) reported $75 \%$ of $\mathrm{Zn}$ in the PS matrix in the $20-0.45 \mu \mathrm{m}$ size-fraction. Masse et al. (2005) found $80 \%$ of PS-Zn in the $10-0.45 \mu \mathrm{m}$ particle-size range.

Hence, the 20-0.2 $\mu \mathrm{m}$ fraction was selected for SEM-EDS analysis. After extensive examination, the single region on the analyzed sample surface that contained $\mathrm{Zn}$ in the elemental composition was selected as presented in Figure 2. The diameter of the two detected particles was about $1 \mu \mathrm{m}$ (Figure $2 \mathrm{~b}$ ). It should be noted that the particles appeared to have a disordered long-range structure, especially particle \#2. One possible explanation is that they consisted of micro-sized aggregates of smaller-(nano-)sized sub-units. Both contained mostly $\mathrm{Zn}$ and $\mathrm{S}$ in their elemental composition, but also low intensity peaks indicating the presence of $\mathrm{Ca}$ and $\mathrm{K}$ cations (Figure $2 \mathrm{c}$ ). The co-location of $\mathrm{Zn}$ and $\mathrm{S}$ may be attributed to the presence of $\mathrm{ZnS}$, which was previously observed in only one study (Legros et. al, 2010a). We conducted EXAFS analysis to test this hypothesis. 


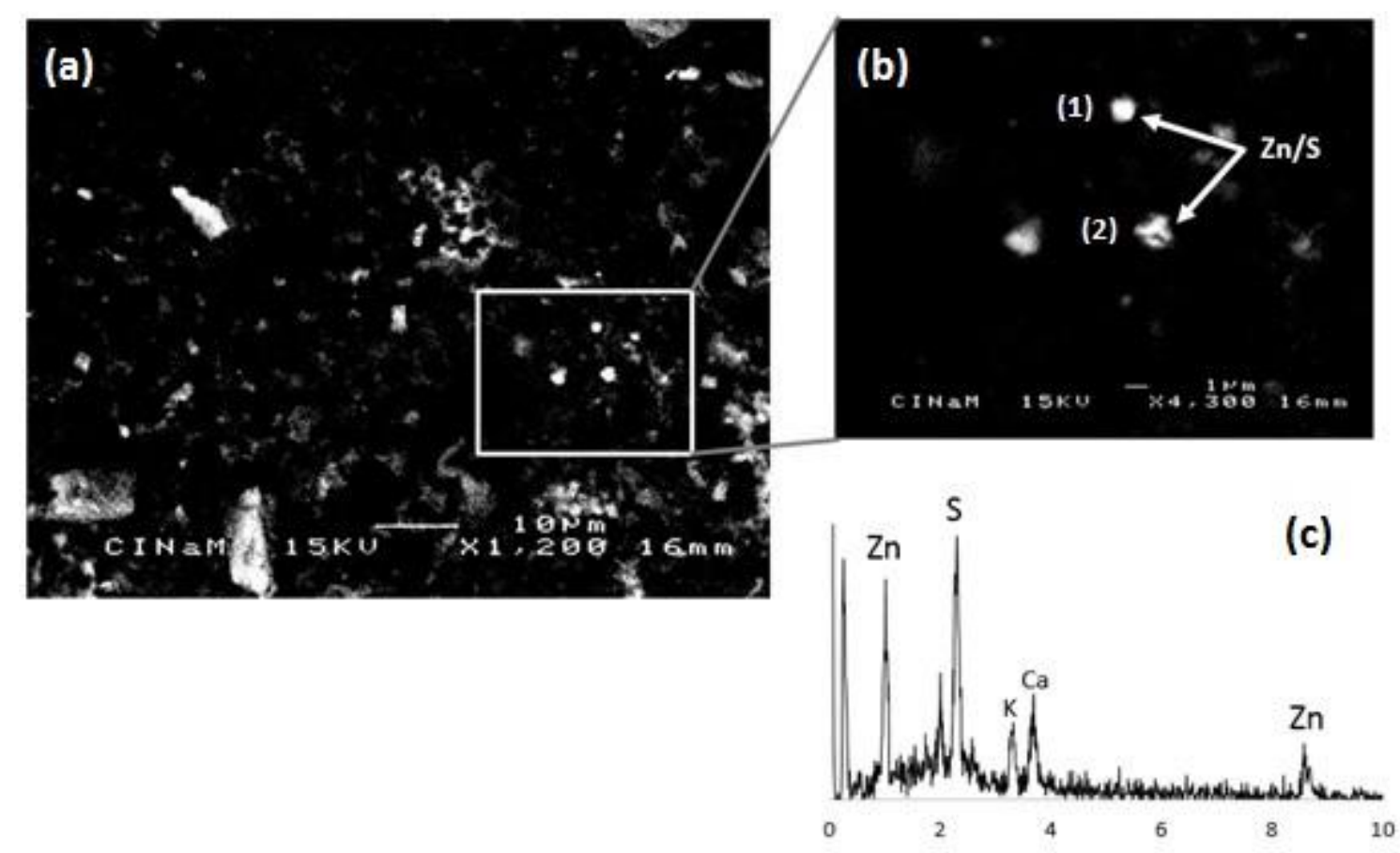

Figure $2-(a, b)$ Scanning electron microscopy micrograph of the 20-0.2 $\mu \mathrm{m}$ PS fraction; arrows indicate regions selected for energy dispersive X-ray spectroscopy (c).

\subsubsection{Nano-sized ZnS particles in PS}

The EXAFS spectra of the PS sample presented oscillation patterns in close agreement with the synthesized ZnS references. Figure 3a presents the EXAFS and Fourier transform (FT) spectra of the PS superposed by the spectra of the bulk (Aldrich) and the synthesized nano-ZnS with different particle sizes: $\mathrm{ZnS}_{[2.5 \mathrm{~nm}]}, \mathrm{ZnS}_{[4.7 n m]}$, and $\mathrm{ZnS}_{[5.9 \mathrm{~nm}]}$ (Section 2.7). The bulk $\mathrm{ZnS}$ spectrum was characterized by sharp and high amplitude EXAFS oscillations as compared to the PS sample and the nano-sized ZnS references. This was reflected in the FT spectra, in which the bulk ZnS displayed the highest intensity peaks. In bulk ZnS, the FT peak at $1.9 \AA$ (not phaseshifted) indicated that the first $\mathrm{Zn}$ coordination shell was consisted of four $\mathrm{S}$ atoms located $2.34 \AA$ from the central atom (Legros et al., 2010a). The FT peak centered at $3.7 \AA$ originated from the $\mathrm{Zn}-\mathrm{Zn}$ interaction in the second coordination shell, with a bonding distance of $3.87 \AA$ and a coordination number of 12 (Roberts et al., 2002). Moreover, the second peak at $3.7 \AA$ may have received a contribution from the $\mathrm{Zn}-\mathrm{S}$ interaction in the third coordination shell.

The lower amplitude, sharpness (EXAFS) and intensity (FT) in spectra of the synthesized nano-ZnS references and the PS sample (compared to the bulk ZnS) may have been due to the greater proportion of under-coordinated $\mathrm{Zn}$ atoms located at the particle surfaces, causing a decrease in the average number of $\mathrm{Zn}$ neighbors. This is confirmed in the 
second FT peak (centered at $3.7 \AA$ ) in Figure 3a, in which the peak intensity declines with the ZnS particle-size.

The spectral features of the PS sample and the $\mathrm{ZnS}_{[4.7 \mathrm{~nm}]}$ reference presented the most pronounced similarity, both in the EXAFS and FT. This was confirmed by the LCF procedure. The best LCF for the PS sample was nearly perfectly adjusted to the sample spectra and was achieved by using only one component: $\mathrm{ZnS}_{[4.7 n m]}$ (Figure $3 b$ ).
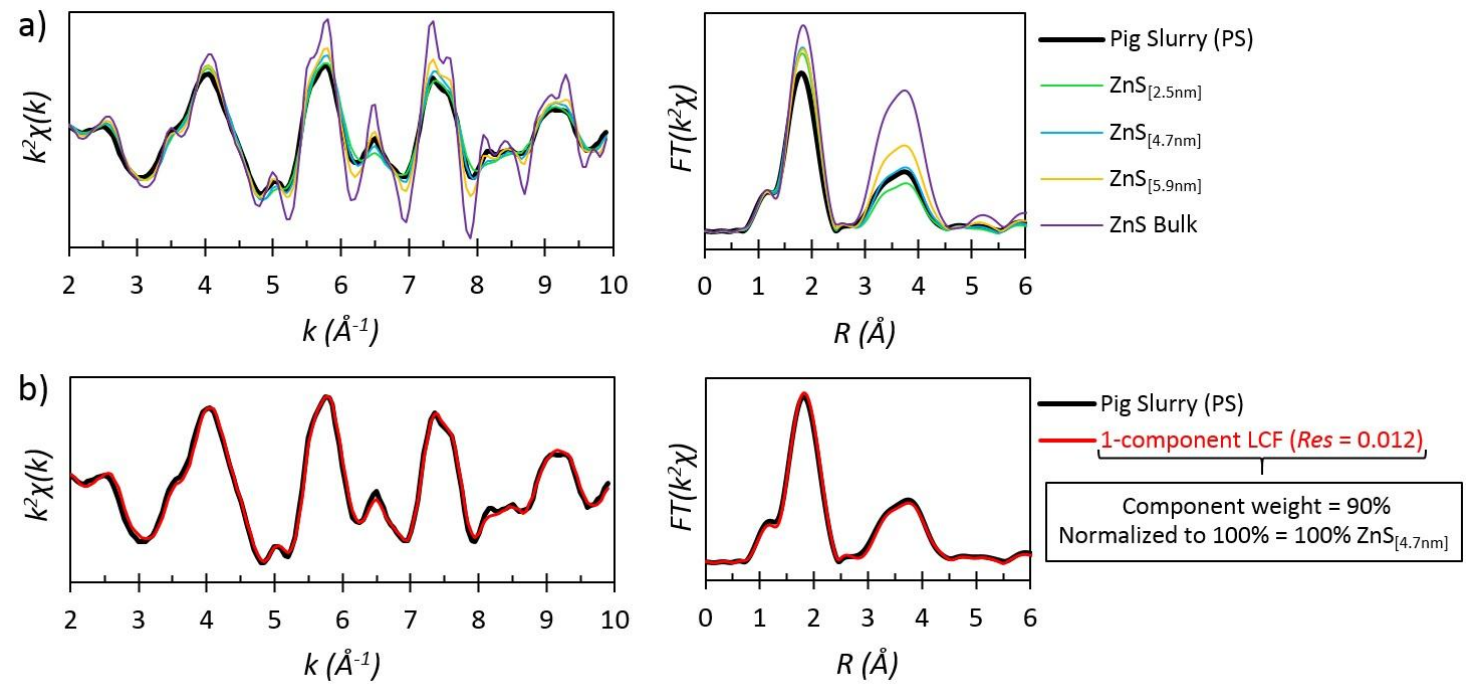

Figure $3-$ (a) $k^{2}$-weighted Zn K-edge EXAFS and FT spectra of the PS sample compared to bulk and nanosized ZnS; (b) 1-component LCF for the PS sample.

Although EXAFS analysis may not be conclusive on particle-size determination, it may be assumed that the $\mathrm{ZnS}$ phase detected here in the PS had a relatively disordered structure compared to the bulk ZnS. We put forward the hypothesis that these ZnS particles were nanosized. This is in agreement with our SEM-EDS analysis that showed the co-location of $\mathrm{Zn}$ and S in 1- $\mu \mathrm{m}$ units that should have been formed by aggregation of nano-sized particles (Section 3.1.1; Figure 2). A very similar trend was recently observed in a sewage sludge product (Kim et al., 2014). The authors used TEM-based techniques to report ZnS nanocrystals with a 2.5-7.5 $\mathrm{nm}$ diameter range, forming aggregates of a few hundred $\mathrm{nm}$. Moreover, in the latter study, the LCF of the sewage sludge spectra was consistent with the $\mathrm{Zn}$ local structure of a 3-nm ZnS reference material.

A few studies have been conducted on $\mathrm{Zn}$ speciation in PS, notably via sequential extractions. L'Herroux et al. (1997) reported a mixture of $\mathrm{Zn}$ bound to carbonate and $\mathrm{Zn}$ bound to oxides, whereas Miaomiao et al. (2009) found a mixture of $\mathrm{Zn}$ bound to oxides, $\mathrm{Zn}$ bound to organic matter ( $\mathrm{n} n-\mathrm{OM})$, and $\mathrm{Zn}$ in the residual fraction. Legros et al. (2010a), in a study 
involving combined SEM-EDS and XAS analysis, reported for the first time the presence of ZnS particles in the PS matrix, along with $\mathrm{Zn}-\mathrm{OM}$ and amorphous $\mathrm{Zn}$ hydroxides. The $\mathrm{ZnS}$ contribution to $\mathrm{Zn}$ speciation was $14 \%$, and particles were about $5-\mu \mathrm{m}$ diameter.

To our knowledge, the present study is the first: (i) in which ZnS accounted for $100 \%$ of the $\mathrm{Zn}$ speciation in the PS matrix, and (ii) to provide evidence that $\mathrm{ZnS}$ in the PS was nanosized. The anoxic environment within PS lagoons is consistent with the formation of $\mathrm{Zn}$ sulfides by two possible mechanisms: chemical precipitation or bacteria-assisted sulfate reduction (Legros et al., 2010a). We attribute our novel findings to the special care we took to preserve the sample anaerobic conditions during the sampling and storage procedures (Section 2.3). This was not the case for other studies in which samples were vigorously shaken (L'Herroux et al., 1997), collected from a forced-aeration treatment process (Miaomiao et al., 2009), or in which no specific care was taken concerning sample oxidation (Legros et al., 2010a). Note also that precipitation of nano-sized ZnS particles might be favored in PS because of the high amount of OM that likely prevents the growth of ZnS particles by sorbing on their surfaces.

Furthermore, the PS containing $100 \%$ ZnS was spread on the soil over an 11-year period, totaling 22 applications. The resulting $\mathrm{Zn}$ speciation within the amended soil, as compared to the control soil and the PS, was then explored via EXAFS and XRD analysis.

3.3 Soil

3.3.1 Clays dominate the soil mineralogy

The X-ray diffractogram of the bulk soil is shown in Figure 4. The soil mineralogy was dominated by the phyllosilicates vermiculite and kaolinite, the aluminum hydroxide gibbsite, the Fe oxide hematite, and quartz. Therefore, vermiculite, kaolinite and hematite species were logical candidates with respect to potentially bearing $\mathrm{Zn}$ and were considered in the EXAFS analysis of the soil. 


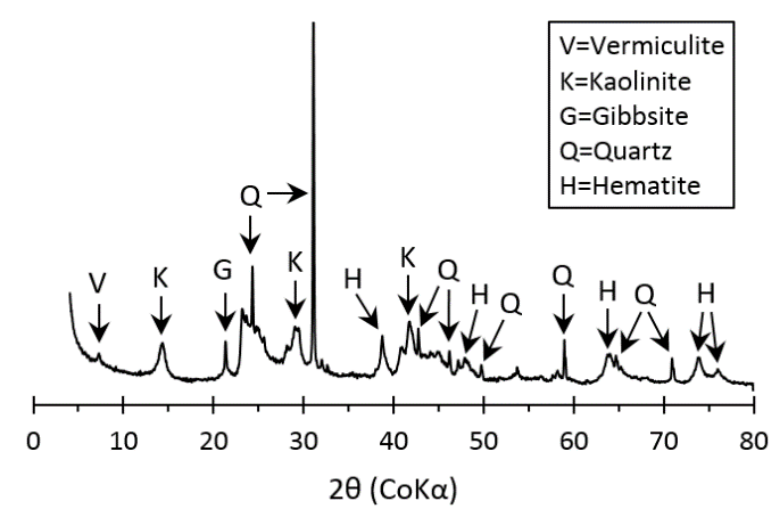

Figure 4 - X-ray diffractogram of the studied soil $(\lambda=1.79 \AA)$.

\subsubsection{ZnS was not detected in the amended soil}

The $k^{2}$-weighted Zn K-edge EXAFS and FT spectra of the control soil and the amended soil, as compared to $\mathrm{Zn}$ sorbed on the selected references, are shown in Figure 5 . The references presented in Figure 5 were selected from the large database of $\mathrm{Zn}$ reference materials presented in Section 2.6 based on the most representative $\mathrm{Zn}$ species used in the LCF procedure (to be presented in this section), while taking the soil composition into account (Section 3.3.1).

Both the control and amended soils displayed marked splitting in the first EXAFS oscillation, at $3.75 \AA^{-1}$ (dashed line "a"), coincident with the Zn-kaolinite reference. In this reference, splitting was due to the $\mathrm{Zn}-\mathrm{Al}$ interaction in the second coordination shell, when $\mathrm{Zn}$ occupied dioctahedral vacancies in gibbsitic hydroxy-Al polymers. The $\mathrm{Zn}$-Al interaction was reflected by the FT peaks at $2.6 \AA$ and $5.5 \AA$ (not phase-shifted, dashed lines " $\mathrm{b}$ " and " $c$ ", respectively) (Jacquat et al., 2009a; Jacquat et al., 2009b; Schlegel \& Manceau, 2007). Spectral signatures "a", " $b$ " and " $c$ " were coincident in the soil samples and in the Zn-kaolinite reference, indicating that Zn-kaolinite may have dominated Zn speciation in the soil samples.

The spectra of $\mathrm{Zn}$-ferrihydrite presented distinct oscillation patterns, reflecting the different $\mathrm{Zn}$ local environment in this Fe oxyhydroxide. The FT peak near $1.5 \AA$ (not phaseshifted, dashed line " $\mathrm{d}$ ") was slightly shifted to a shorter distance as compared to the $\mathrm{Zn}$ kaolinite reference (dashed line " $e$ "). Complexes on the ferrihydrite surface had $\mathrm{Zn}-\mathrm{O}$ distances of around $1.97 \AA$ and coordination numbers consistent with tetrahedral oxygen, as opposed to $\mathrm{Zn}-\mathrm{O}$ distances of around $2.11 \AA$ in octahedral coordination. Moreover, the FT peak at $3.2 \AA$ (not phase-shifted, dashed line " $f$ ") arose from the $\mathrm{Zn}$-Fe interaction in the second coordination shell, at $3.44 \AA$ distance (Waychunas et al., 2002). Therefore, Zn-ferrihydrite was 
used as a proxy to represent tetrahedrally coordinated adsorbed/complexed $\mathrm{Zn}$ on $\mathrm{Fe}$ (oxyhydr)oxides (Voegelin et al., 2011), denoted "Zn-Fe (oxyhydr)oxide" hereafter.

In the $\mathrm{Zn}$-malate complex, the first $\mathrm{Zn}-\mathrm{O}$ coordination shell was octahedral, and the second shell was composed of $\mathrm{C}$ and $\mathrm{O}$ atoms. Since $\mathrm{Zn}$-malate is a common organic acid present in soils, it was used as LCF proxy to account for $\mathrm{Zn}$ bound to organic matter (Sarret et al., 2002; Jones et al., 1996), denoted "Zn-OM" hereafter.
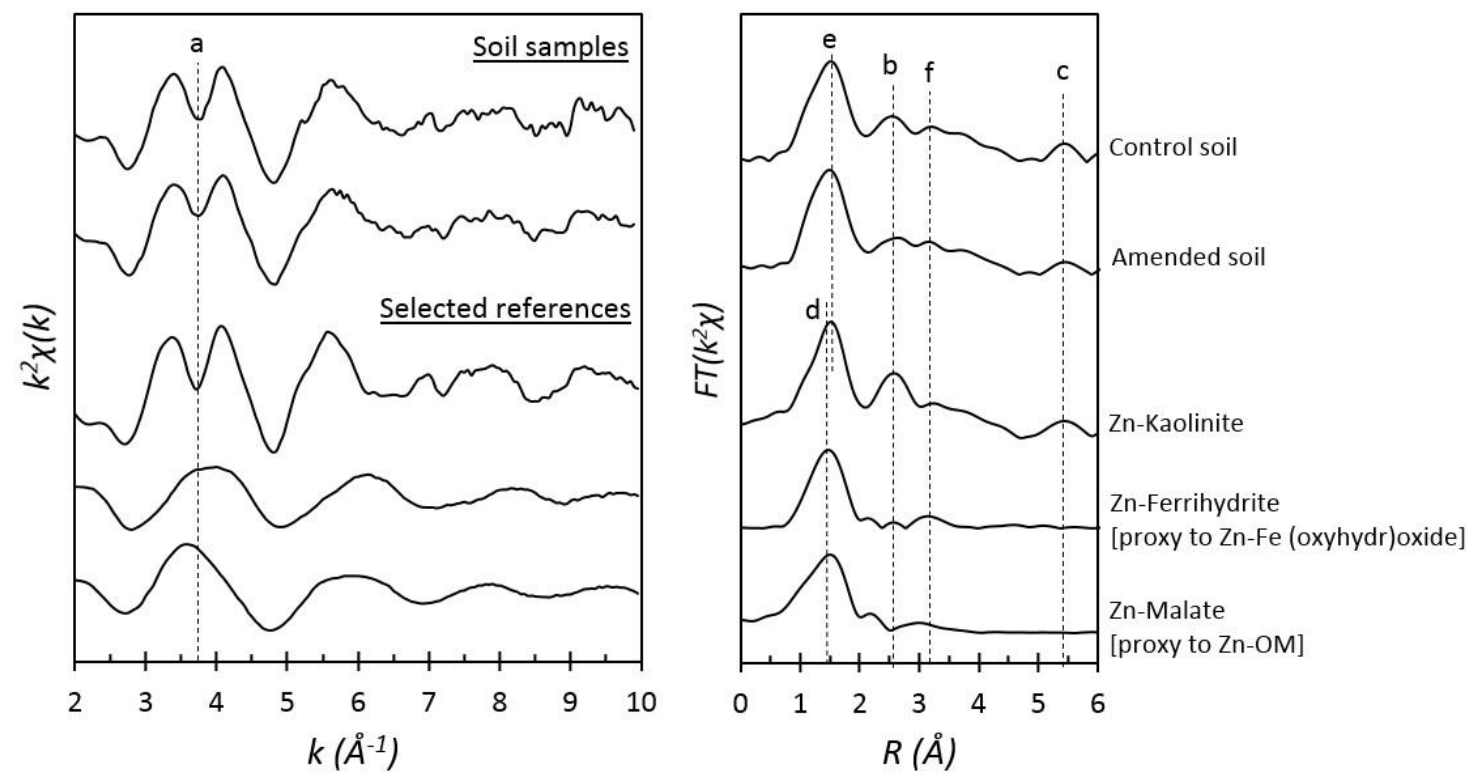

Figure $5-k^{2}$-weighted Zn K-edge EXAFS and FT spectra of the control and amended soils as compared to the selected references.

The spectra of the control soil and the amended soil, superposed by their best LCF using the $\mathrm{Zn}$ reference database (Section 2.6), are shown in Figure 6. The best LCF for the control soil using two components used Zn-kaolinite and Zn-Fe (oxyhydr)oxide. Adding a third component ( $\mathrm{Zn}-\mathrm{OM}$ in the best fit) did not lead to a better reproduction of the sample spectra, and the decrease in the Res parameter was below $20 \%$. Hence, the two-component LCF was the best solution. We attributed the contribution of the $\mathrm{Zn}$-Fe (oxyhydr)oxide proxy reference to $\mathrm{Zn}$-hematite, supported by the XRD observation of hematite in the soil composition (Section 3.1).

The LCF for the amended soil using two components was also achieved by combining the same references as in the control soil: Zn-kaolinite and Zn-Fe (oxyhydr)oxide. Nevertheless, adding a third component to the fit ( $\mathrm{Zn}-\mathrm{OM})$ improved the reproduction of the sample EXAFS spectrum, notably in the first half of the main oscillation (pointing arrow "a"). Moreover, the 
resulting FT spectrum in the three-component scenario showed an increased amplitude in the first peak, followed by a decrease and a shift to a higher distance in the second peak as compared to the two-component scenario (pointing arrows " $b$ " and " $c$ "). The visual improvement in the quality of the LCF when adding the third component was confirmed by the more than $20 \%$ decrease in the Res parameter as compared to the two-component LCF. Hence, the three-component LCF was the optimal solution.

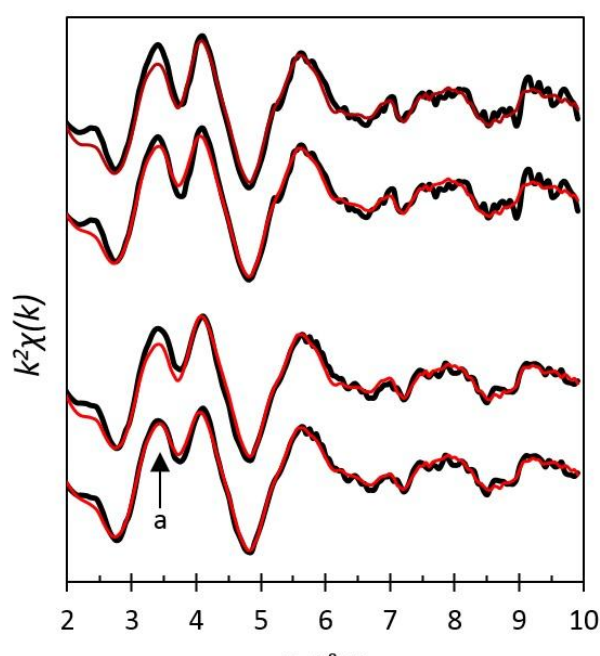

$k\left(\AA^{-1}\right)$

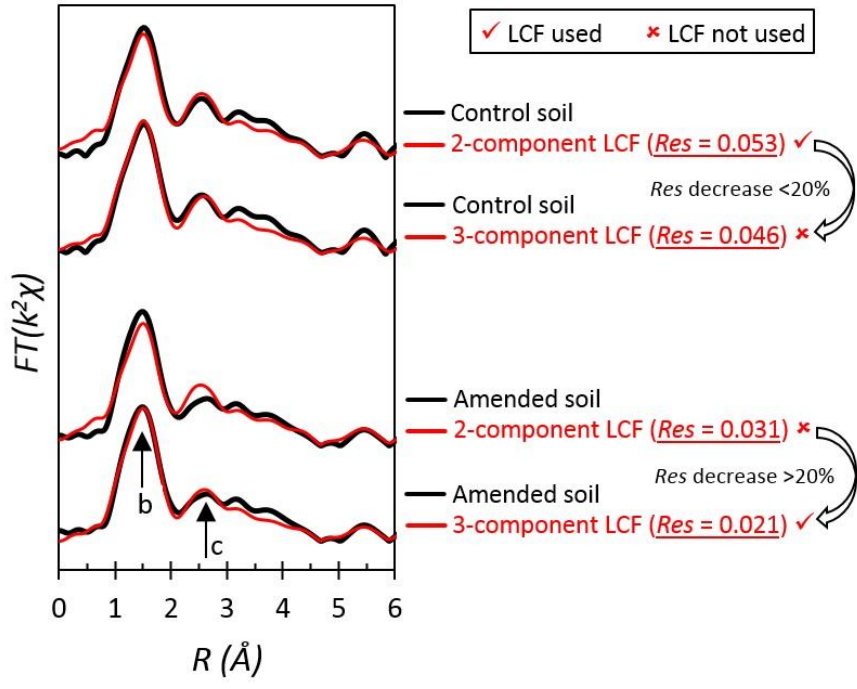

$R(\AA ̊)$

$\checkmark$ Control soil, 2-component LCF: Sum of weights $=102 \%$; Normalized to $100 \%=70 \%$ Zn-kaolinite $/ 30 \%$ Zn-Fe (oxyhydr)oxide $\checkmark$ Amended soil, 3-component LCF: Sum of weights $=112 \%$; Normalized to $100 \%=54 \%$ Zn-kaolinite $/ 27 \%$ Zn-Fe (oxyhydr)oxide $/ 19 \%$ Zn-OM

Figure $6-k^{2}$-weighted Zn K-edge EXAFS and FT spectra of the control and amended soils, and the optimal LCF for each sample.

The resulting $\mathrm{Zn}$ speciations in the control soil, amended soil and PS are presented in Figure 7. The concentration of each $\mathrm{Zn}$ species within the soil samples was obtained by multiplying the normalized LCF proportions with the total Zn content in each soil (Section 3.1). The control soil $\left(\mathrm{Zn}=100.4 \mathrm{mg} \mathrm{kg}^{-1}\right)$ contained $70 \% \mathrm{Zn}$-kaolinite $\left(70.3 \mathrm{mg} \mathrm{kg}^{-1}\right)$ and $30 \% \mathrm{Zn}-\mathrm{Fe}$ (oxyhydr)oxide $\left(30.1 \mathrm{mg} \mathrm{kg}^{-1}\right)$. The amended soil $\left(\mathrm{Zn}=188.1 \mathrm{mg} \mathrm{kg}^{-1}\right)$ contained $54 \% \mathrm{Zn}$ kaolinite $\left(101.6 \mathrm{mg} \mathrm{kg}^{-1}\right), 27 \% \mathrm{Zn}$-Fe (oxyhydr)oxide $\left(50.8 \mathrm{mg} \mathrm{kg}^{-1}\right)$ and 19\% Zn-OM (35.7 $\left.\mathrm{mgkg}^{-1}\right)$.

Hence, $\mathrm{Zn}$ species originally present in the control soil [Zn-kaolinite and Zn-Fe (oxyhydr)oxide], plus $\mathrm{Zn}-\mathrm{OM}$ (not detected in the control soil) were responsible for the assimilation of exogenous $\mathrm{Zn}$, in the following proportions: $36 \% \mathrm{Zn}$-kaolinite, $23 \% \mathrm{Zn}$-Fe (oxyhydr)oxide and $41 \% \mathrm{Zn}-\mathrm{OM}$. It should be stressed that the ZnS contained in the PS was the only exogenous source of $\mathrm{Zn}$ within the amended soil. It caused a $\mathrm{Zn}$ concentration increase from $100.4 \mathrm{mg} \mathrm{kg}^{-1}$ in the control soil to $188.1 \mathrm{mg} \mathrm{kg}^{-1}$ in the amended soil $(0-5 \mathrm{~cm}$ layer; Figure 1). However, this species (ZnS) was not detected in the amended soil. Besides the LCF 
procedure, visual comparison between the spectral features of the ZnS-containing PS sample (Figure 3) and the amended soil (Figure 5) clearly confirmed the radical change in PS-borne Zn speciation after spreading on the soil. None of the EXAFS or FT spectral features coincided when comparing these two samples (PS vs amended soil). This rules out any possible underestimation or misinterpretation of the potential contribution of the PS-borne $\mathrm{ZnS}$ to $\mathrm{Zn}$ speciation in the amended soil.

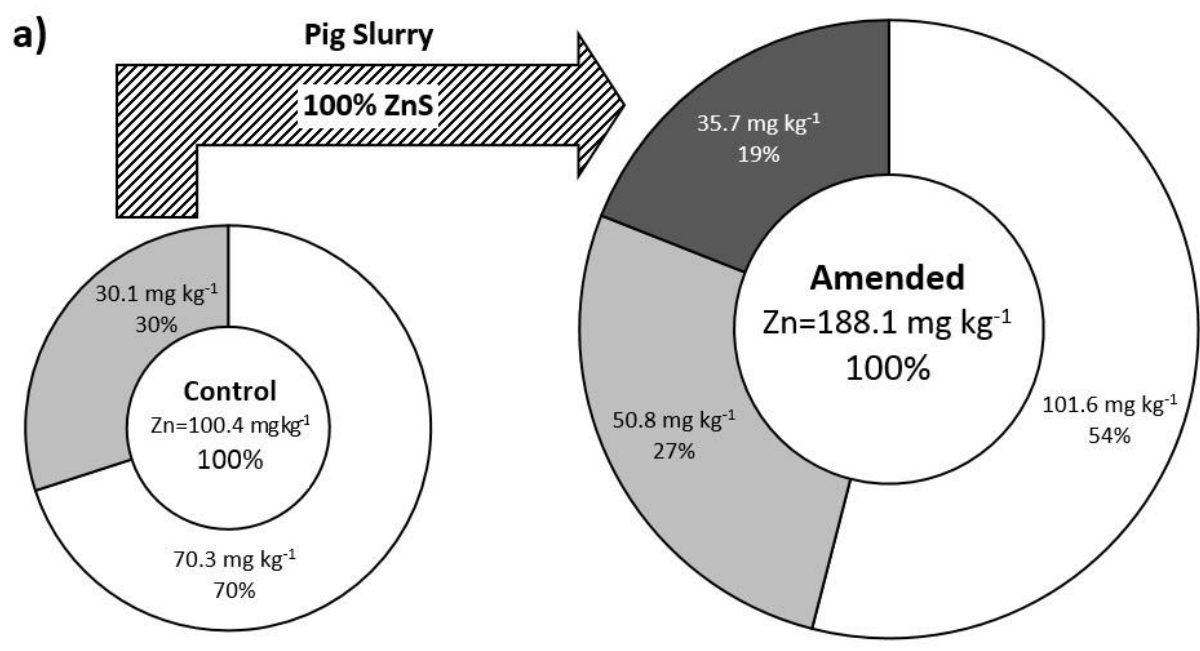

b)

Exogenous Zn distribution (amended - control $=87.7 \mathrm{mg} \mathrm{kg}^{-1}$ )

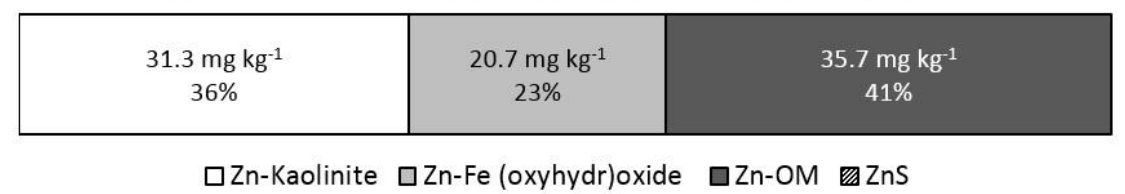

Figure 7 - (a) Zn speciation within the control and amended soils and the PS; and (b) the resulting exogenous $Z n$ distribution.

\subsection{Environmental implication}

The solubility constant of sphalerite (i.e. $\mathrm{ZnS}$ ) is $2.93 \times 10^{-36}$ (Robert et al., 1988). It would therefore be expected to be highly insoluble, although the solubility may be influenced by the media composition, $\mathrm{pH}$ and redox conditions (Moreau et al., 2004; Martínez \& Motto, 2000). Indeed, particulate transfer of micrometer-sized ZnS was the predominant mechanism of $\mathrm{Zn}$ propagation within the soil 18 months after spreading a ZnS-rich dredged sediment (Isaure et al., 2005). Nevertheless, the authors observed $\mathrm{Zn}$ leaching peaks when the oxidative dissolution of ZnS was favored by non-flooding conditions. Voegelin et al. (2011) reported 26\% to $75 \%$ dissolution of $25-40-n m$ crystallite $\mathrm{ZnS}$ after 4 years of soil incubation. $\mathrm{ZnS}$ dissolution 
was slower in acidic soils, as compared to either a near neutral or a calcareous soil. Except for the calcareous soil, ZnS also dissolved more slowly compared to $\mathrm{ZnO}$.

Moreover, reactivity of metal sulfides depends on the particle size, morphology, and crystal structure (Hochella et al., 2008; Liu et al., 2009), which may in turn be related to the formation process. The resistance of $\mathrm{ZnS}$ to re-oxidation was in the following order: sphalerite mineral $>\mathrm{ZnS}$ formed by $\mathrm{SO}_{4}$-reducing-bacteria > chemically precipitated $\mathrm{ZnS}$ (Peltier et al., 2011). The anoxic environment within PS lagoons is consistent with the formation of $\mathrm{Zn}$ sulfides by either bacteria-assisted sulfate reduction or chemical precipitation (Legros et al., 2010a). Indeed, the findings of full scale, pilot and benchtop studies revealed that $\mathrm{Zn}$ sulfidation was dominant during anaerobic digestion of wastewater and in sewage sludge (Kim et al., 2014; Lombi et al., 2012; Ma et al., 2014).

Reducing the size of $\mathrm{ZnS}$ nanoparticles from 100 to $1 \mathrm{~nm}$ radius theoretically increased their solubility in water by five orders of magnitude (Moreau et al., 2004). Strain-driven distortion has been observed for small disordered ZnS nanoparticles ( 3-nm), which could potentially reduce their stability (Gilbert et al. 2004), as for instance observed in submicrometer ZnS phases present in river suspended particulate matter when exposed to oxic environments (Priadi et al. 2012).

Therefore, the radical change in PS-borne $\mathrm{Zn}$ speciation following land application observed in this study was consistent with the presence of nano-sized ZnS particles in the PS matrix. This was supported by: (i) our SEM-EDS (Section 3.2.1) and XAS (Sections 3.2.2 and 3.3.2) observations; and (ii) by previous literature data (presented in this section), highlighting the influence of the particle size and structure, as well as the type of environment (e.g. oxic or anoxic), on the stability of such particles.

\section{CONCLUSION}

In the present study, we: (i) identified, via SEM-EDS, aggregates of about 1- $\mu \mathrm{m}$ diameter in the PS matrix, composed mostly of Zn and S; (ii) reported, using EXAFS, that ZnS accounted for $100 \%$ of the $\mathrm{Zn}$ speciation, most likely at the nano-scale, thus supporting our SEM-EDS observations; and (iii) verified that the $\mathrm{Zn}$ applied to the soil via PS spreading was not present in the form of $\mathrm{ZnS}$, after 22 applications over 11 years, although this was the only source of $\mathrm{Zn}$ during the period. 
Considering the nature of $\mathrm{Zn}$ added to the pig feed (sulfate), the nature of the lagoon used in the pig waste treatment (anoxic), and the results reported here, the most likely explanation for our findings is that: (i) dissolved $\mathrm{Zn}$ species reacted in situ with reduced $\mathrm{S}$ to form ZnS nanocrystals in the anaerobic lagoon; (ii) the formation process (chemical precipitation or bacteria-assisted sulfate reduction) and the nano-scale of the PS-borne ZnS favored the oxidation of this species within the soil, releasing $\mathrm{Zn}$ that was subsequently retained by phyllosilicates, Fe (oxyhydr)oxides and OM in the soil.

\section{ACKNOWLEDGEMENTS}

The authors are grateful to Copercampos for authorizing this study in its experimental plots, and to Epagri for providing the soil samples. The authors also wish to thank Andreas Voegelin (Zn-kaolinite reference), Bernard Angeletti (ICP-MS assistance), Daniel Borschneck (XRD assistance), Nathan Bossa (PS filtration and SEM-EDS assistance), Olivier Grauby (SEMEDS assistance), Patrícia Dall' Agnol and Rafael Gotardo (PS sampling assistance). T.A. Formentini acknowledges CAPES for a postgraduate scholarship (99999.000142/2014-00) and UFSM for the leave of absence. This research used resources of the Advanced Photon Source, a U.S. Department of Energy (DOE) Office of Science User Facility operated for the DOE Office of Science by Argonne National Laboratory under Contract No. DE-AC02-06CH11357. We acknowledge the European Synchrotron Radiation Facility for provision of synchrotron radiation facilities and we would like to thank Isabelle Kiefer for assistance in using beamline BM30B.

\section{SUPPORTING INFORMATION AVAILABLE}

TEM images and XRD characterization of synthesized ZnS nanoparticles used as reference materials for the EXAFS analysis of PS. 


\section{REFERENCES}

ASADA, K.; YABUSHITA, Y.; SAITO, H.; NISHIMURA, T. Effect of long-term swine-manure application on soil hydraulic properties and heavy metal behaviour. European Journal of Soil Science, v. 63, n. 3, p. 368-376, 2012.

DOELSCH, E.; BASILE-DOELSCH, I.; ROSE, J. BORSCHNECK, D.; HAZEMANN, J. L.; MACARY, H. S.; BOTTERO, J. Y. New combination of EXAFS spectroscopy and density fractionation for the speciation of chromium within an andosol. Environmental Science \& Technology, v. 40, n. 24, p. 7602-7608, 2006.

DOELSCH, E.; MOUSSARD, G.; MACARY, H. S. Fractionation of tropical soilborne heavy metals Comparison of two sequential extraction procedures. Geoderma, v. 143, n. 1-2, p. 168-179, 2008.

EC - EUROPEAN COMISSION. Making the most of pig manure. 2014. Available at: <http://ec.europa.eu/programmes/horizon2020/en/news/making-most-pig-manure>. Accessed 2015, June $15^{\text {th }}$.

FAO - FOOD AND AGRICULTURE ORGANIZATION OF THE UNITED NATIONS. Statistics Division: FAOSTAT. 2013. Available at: <http://faostat3.fao.org/home/E> Accessed 2015, June $18^{\text {th }}$.

FORMENTINI, T. A.; MALLMANN, F. J. K.; PINHEIRO, A.; FERNANDES, C. V. S.; BENDER, M. A.; VEIGA, M.; SANTOS, D. R.; DOELSCH, E. Copper and zinc accumulation and fractionation in a clayey Hapludox soil subject to long-term pig slurry application. Science of the Total Environment, v. 536, 831-839, 2015.

GILBERT, B.; HUANG, F.; ZHANG, H.; WAYCHUNAS, G. A.; BANFIELD, J. F. Nanoparticles: strained and stiff. Science, v. 305, p. 651-654, 2004.

GIROTTO, E.; CERETTA, C. A.; BRUNETTO, G.; SANTOS, D. S.; SILVA, L. S.; LOURENZI, C. R.; LORENSINI, F.; VIEIRA, R. C. B.; SCHMATZ, R. Acúmulo e formas de cobre e zinco no solo após aplicações sucessivas de dejeto líquido de suínos. Revista Brasileira de Ciências do Solo, v. 34, n. 3, p. 955-965, 2010.

GRÄBER, I.; HANSEN, J. F.; OLESEN, S. E.; PETERSEN, J.; ØSTERGAARD, H. S.; KROGH, L. Accumulation of Copper and Zinc in Danish Agricultural Soils in Intensive Pig Production Areas. Danish Journal of Geography, v. 105, p. 15-22, 2005.

GUAN, T. X.; HE, H. B.; ZHANG, X. D.; BAI, Z. Cu fractions, mobility and bioavailability in soil-wheat system after Cu-enriched livestock manure applications. Chemosphere, v. 82, n. 2, p. 215-22, 2011.

HERNÁNDEZ, D.; PLAZA, C.; SENESI, N; POLO, A. Detection of copper(II) and zinc(II) binding to humic acids from pig slurry and amended soils by fluorescence spectroscopy. Environmental Pollution, v. 143, p. 212-220, 2006.

HOCHELLA, M. F.; LOWER, S. K.; MAURICE, P. A.; PENN, R. L.; SAHAI, N.; SPARKS, D. L.; TWINING. B. S. Nanominerals, mineral nanoparticles, and earth systems. Science, v. 319, p. 1631-1635, 2008.

HSEU, Z.-Y. Extractability and bioavailability of zinc over time in three tropical soils incubated with biosolids. Chemosphere, v. 63, n. 5, p. 762-771, 2006.

ISAURE, M. P.; MANCEAU, A.; GEOFFROY, N.; LABOUdIGUE, A.; TAMURA N.; MARCUS, M. A. Zinc mobility and speciation in soil covered by contaminated dredged sediment using micrometer-scale and bulk-averaging X-ray fluorescence, absorption and diffraction techniques. Geochimica et Cosmochimica Acta, v. 69, n. 5, p. 1173-1198, 2005.

JACQUAT, O.; VOEGELIN, A.; KRETZSCHMAR, R. Local coordination of Zn in hydroxy-interlayered minerals and implications for Zn retention in soils. Geochimica et Cosmochimica Acta, v. 73, 348-363, 2009 a.

JACQUAT, O.; VOEGELIN, A.; KRETZSCHMAR, R. Soil properties controlling $\mathrm{Zn}$ speciation and fractionation in contaminated soils. Geochimica et Cosmochimica Acta, v. 73, p. 5256-5272, 2009 b. 
JONDREVILLE, C.; REVY, P. S.; DOURMAD, J. Y. Dietary means to better control the environmental impact of copper and zinc by pigs from weaning to slaughter. Livestock Production Science, v. 84, n. 2, p. 147156, 2003.

JONES, D. L.; PRABOWO, A. M.; KOCHIAN, L. V. Kinetics of malate transport and decomposition in acid soils and isolated bacterial populations: The effect of microorganisms on root exudation of malate under Al stress. Plant and Soil, v. 182, p. 239-247, 1996.

KIM, B.; LEVARD, C.; MURAYAMA, M.; BROWN, G. E; HOCHELLA, M. F. Integrated approaches of x-ray absorption spectroscopic and electron microscopic techniques on zinc speciation and characterization in a final sewage sludge product. Journal of Environmental Quality, v. 43, p. 908-916, 2014.

KIRPICHTCHIKOVA, T. A.; MANCEAU, A.; SPADINI, L.; PANFILI, F.; MARCUS, M. A; JACQUET, T. Speciation and solubility of heavy metals in contaminated soil using X-ray microfluorescence, EXAFS spectroscopy, chemical extraction, and thermodynamic modeling. Geochimica et Cosmochimica Acta, v. 70, p. 21632190, 2006.

L'HERROUX, L.; LE ROUX, S.; APPRIOU, P.; MARTINEZ, J. Behaviour of metals following intensive pig slurry applications to a natural field treatment process in Brittany (France). Environmental Pollution, v. 97, n. 1, p. 119-130, 1997.

LEGROS, S.; DOELSCH, E.; MASION, A.; ROSE, J.; BORSCHNECK, D.; PROUX, O.; HAZEMANN, J-L.; SAINTMACARY, H.; BOTTERO, J-Y. Combining size fractionation, scanning electron microscopy, and X-ray absorption spectroscopy to probe zinc speciation in pig slurry. Journal of Environmental Quality, v. 39, n. 2, p. 531-540, 2010a.

LEGROS, S.; CHAURAND, P.; ROSE, J.; MASION, A.; BRIOIS, V.; FERRASSE, J-H.; MACARY, H. S.; BOTTERO, J-Y.; DOELSCH, E. Investigation of copper speciation in pig slurry by a multitechnique approach. Environmental Science \& Technology, v. 44, n. 18, p. 6926-6932, 2010 b.

LEGROS, S.; DOELSCH, E.; FEDER, F.; MOUSSARD, G.; SANSOULET, J.; GAUDET, J. P.; RIGAUD, S.; BASILE DOELSCH, I.; MACARY, H. S.; BOTTERO, J-Y. Fate and behaviour of $\mathrm{Cu}$ and $\mathrm{Zn}$ from pig slurry spreading in a tropical water-soil-plant system. Agriculture, Ecosystems \& Environment, v. 164, p. 70-79, 2013.

LIN, Q.; LIANG, L.; WANG, L. H.; NI, Q. L.; YANG, K.; ZHANG, J.; CHEN, D. L.; YANG, J. J.; SHEN, X. D. Roles of pyrolysis on availability, species and distribution of $\mathrm{Cu}$ and $\mathrm{Zn}$ in the swine manure: chemical extractions and high-energy synchrotron analyses. Chemosphere, v. 93, p. 2094-2100, 2013.

LIPOTH, S. L.; SCHOENAU, J. J. Copper, zinc, and cadmium accumulation in two prairie soils and crops as influenced by repeated applications of manure. Journal of Plant Nutrition and Soil Science, v. 170, n. 3, p. 378-386, 2007.

LIU, J.; ARUGUETE D.; MURAYAMA M.; HOCHELLA M. F. Influence of size and aggregation on the reactivity of an environmentally and industrially relevant nanomaterial (PbS). Environmental Science \& Technology, v. 43, p. 8178-8183, 2009.

LOMBI, E.; DONNER, E.; TAVAKKOLI, E.; TURNEY, T. W.; NAIDU, R.; MILLER, B. W.; SCHECKEL, K. G. Fate of zinc oxide nanoparticles during anaerobic digestion of wastewater and post-treatment processing of sewage sludge. Environmental Science \& Technology, v. 46, p. 9089-9096, 2012.

MALLMANN, F. J. K. Modelagem da transferência de cobre e zinco em solos contaminados por dejeto líquido de suínos. 104 p. Ph.D. thesis (Doutorado em Ciência do Solo), Universidade Federal de Santa Maria, 2013.

MALLMANN, F. J. K.; SANTOS, D. R. D.; CERETTA, C. A.; CELLA, C.; ŠIMŮNEK, J.; VAN OORT, F. Modeling field-scale vertical movement of zinc and copper in a pig slurry-amended soil in Brazil. Journal of Hazardous Materials, v. 243, p. 223-231, 2012. 
MAMINDY-PAJANY, Y.; SAYEN, S.; MOSSELMANS, J.F.; GUILLON, E. Copper, nickel and zinc speciation in a biosolid-amended soil: $\mathrm{pH}$ adsorption edge, $\mu$-XRF and $\mu$-XANES investigations. Environmental Science \& Technology, v. 48, p. 7237-7244, 2014.

MANCEAU, A.; MARCUS, M. A.; TAMURA N. Quantitative speciation of heavy metals in soils and sediments by synchrotron X-ray techniques. In: Applications of Synchrotron Radiation in Lowtemperature Geochemistry and Environmental Science, v. 49. Washington, DC: Mineralogical Society of America, 2002.

MARTINEZ, C. E.; MOTTO, H. L. Solubility of lead, zinc and copper added to mineral soils. Environmental Pollution, v. 107, p. 153-158, 2000.

MASSE, L.; MASSE, D. I.; BEAUDETTE, V.; MUIR, M. Size distribution and composition of particles in raw and anaerobically digested swine manure. Transactions of the ASAE, v. 48, n. 5, p. 1943-1949, 2005.

MIAOMIAO, H.; WENHONG, L.; XINQIANG, L.; DONGLEI, W.; GUANGMING, T. Effect of composting process on phytotoxicity and speciation of copper, zinc and lead in sewage sludge and swine manure. Waste Management, v. 29, p. 590-597, 2009.

MOREAU, J. W.; WEBB, R. I.; BANFIELD, J. F. Ultrastructure, aggregation-state, and crystal growth of biogenic nanocrystalline sphalerite and wurtzite. American Mineralogist, v. 89, p. 950-960, 2004.

PELTIER, E.; ILIPILLA, P.; FOWLE, D. Structure and reactivity of zinc sulfide precipitates formed in the presence of sulfate-reducing bacteria. Applied Geochemistry, v. 26, p. 1673-1680, 2011.

PLEKHANOVA, I. O. Effect of wetting conditions on the fractional composition of heavy metal compounds in agrosoddy-podzolic soils contaminated with sewage sludge. Eurasian Soil Science, v. 45, n. 7, p. 657-664, 2012.

PRIADI, C.; LE PAPE, P.; MORIN, G.; AYRAULT, S.; MAILLOT, F.; JUILLOT, F.; HOCHREUTENER, R.; LLORENS, I.; TESTEMALE, D.; PROUX, O.; BROWN, G. E. X-ray absorption fine structure evidence for amorphous zinc sulfide as a major zinc species in suspended matter from the Seine River downstream of Paris, llede- France, France. Environmental Science \& Technology, v. 46, p. 3712-3720, 2012.

QIAO, X. L.; LUO, Y. M.; CHRSTIE, P.; WONG, M. H. Chemical speciation and extractability of Zn, Cu and Cd in two contrasting biosolids-amended clay soil. Chemosphere, v. 50, p. 823-829, 2003.

RAVEL, B.; NEWVILLE, M. Athena, Artemis, Hephaestus: data analysis for X-ray absorption spectroscopy using IFEFFIT. Journal of Synchrotron Radiation, v. 12, p. 537-541, 2005.

REEDER, R. J.; SCHOONEN, M. A. A.; LANZIROTTI, A. Metal speciation and its role in bioaccessibility and bioavailability. Reviews in Mineralogy and Geochemistry, v. 64, p. 59-113, 2006.

REVY, P. S., JONDREVILLE, C.; DOURMAD, J. Y.; NYS, Y. Le zinc dans l'alimentation du porc: Oligo-élement essentiel et risque potentiel pour l'environnement. INRA Productions Animales, v. 16, p. 3-18, 2003.

ROBERTS, D. R.; SCHEINOST, A C.; SPARKS, D. L. Zinc speciation in a smelter-contaminated soil profile using bulk and microspectroscopic techniques. Environmental Science \& Technology, v. 36, n. 8, p. 1742-1750, 2002.

ROMEO, A.; VACCHINA, V.; LEGROS, S.; DOELSCH, E. Zinc fate in animal husbandry systems. Metallomics, v. 6, p. 1999-2009, 2014.

SARRET, G.; SAUMITOU-LAPRADE, P.; BERT, V.; PROUX, O.; HAZEMANN, J. L.; TRAVERSE, A.; MARCUS, M. A.; MANCEAU A. Forms of zinc accumulated in the hyperaccumulator Arabidopsis halleri. Plant Physiology, v. 130, p. 1815-1826, 2002. 
SCHLEGEL, M. L.; MANCEAU, A. Zn incorporation in hydroxy-Al- and Keggin Al-13-intercalated montmorillonite: a powder and polarized EXAFS study. Environmental Science \& Technology, v. 41, p. 1942-1948, 2007.

TELLA, M.; BRAVIN, M. N.; THURIÈS, L.; CAZEVIEILLE, P.; CHEVASSUS-ROSSET, C.; COLLIN, B.; CHAURAND, P.; LEGROS, S.; DOELSCH, E. Increased zinc and copper availability in organic waste amended soil potentially involving distinct release mechanisms. Environmental Pollution, v. 212, p. 299-306, 2016.

USDA - UNITED STATES DEPARTMENT OF AGRICULTURE. Soil survey staff, keys to soil taxonomy. $9^{\text {th }} \mathrm{ed}$. Washington: Natural Resources Conservation Service, USDA, 2003.

USEPA - UNITED STATES ENVIRONMENTAL PROTECTION AGENCY. Method 3051A: Microwave assisted acid digestion of sediments, sludges, soils, and oils, In: Sw-846 test methods for evaluating solid waste: physical/chemical methods. Washington, 2007.

VEIGA, M.; PANDOLFO, C. M.; JUNIOR, A. A. B.; SPAGNOLLO, E. Chemical attributes of a Hapludox soil after nine years of pig slurry application. Pesquisa Agropecuária Brasileira, v. 47, p. 1766-1773, 2012.

VOEgEliN, A.; JACQUAT, O.; PFISTER, S.; BARMETTLER, K.; SCHEINOST, A. C.; KRETZSCHMAR, R. Timedependent changes of zinc speciation in four soils contaminated with zincite or sphalerite. Environmental Science \& Technology, v. 45, p. 255-261, 2011.

WAYCHUNAS, G. A.; FULLER, C. C.; DAVIS, J. A. Surface complexation and precipitate geometry for aqueous $\mathrm{Zn}$ (II) sorption on ferrihydrite: I. X-ray absorption extended fine structure spectroscopy analysis. Geochimica et Cosmochimica Acta, v. 66, p. 1119-1137, 2002. 


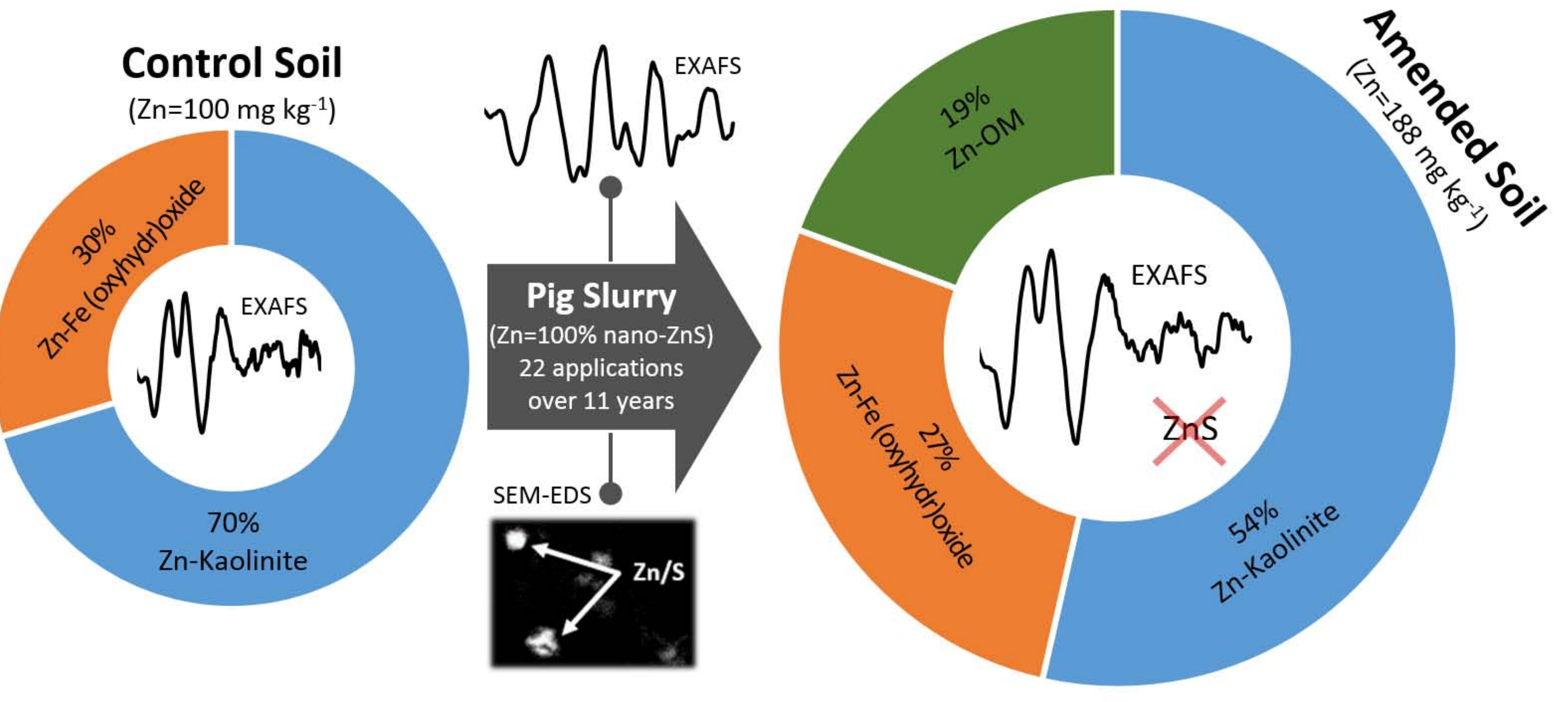

